JIKAP PGSD: Jurnal Ilmiah Ilmu Kependidikan

Vol, 4. No,1. Tahun 2020

e-ISSN: 2597-4440 dan p-ISSN: 2597-4424

This work is licensed under a Creative Commons Attribution

4.0 International License

\title{
Pengaruh Metode Preview, Question, Read, Reflect, Recite and Review (PQ4R) terhadap Membaca Pemahaman Siswa Kelas V SD Inpres Tetebatu Kabupaten Gowa
}

\author{
Nur Afni Dewi Sari ${ }^{1}$, Andi Sukri Syamsuri ${ }^{2}$, Tarman Andi Arif ${ }^{3}$ \\ 1,2,3 Pendidikan Dasar, Program Pascasarjana Universitas Muhammadiyah Makassar \\ Email: ${ }^{1}$ nurafniabid@gmail.com \\ 2andhies71@yahoo.com \\ 3tarman@unismuh.ac.id
}

\begin{abstract}
Abstrak; Tujuan penelitian ini adalah untuk mengetahui pengaruh penerapan metode PQ4R terhadap kemampuan membaca pemahaman siswa. Jenis penelitian yang digunakan dalam penelitian ini adalah penelitian kuantitatif yang sifatnya true experimental dengan menggunakan pretest-posttest control group design. Penelitian ini melibatkan 51 siswa kelas V sekolah dasar sebagai sampel penelitian yang dibagi atas dua kelas yaitu kelas eksperimen dan kelas kontrol. Instrumen yang digunakan adalah tes hasil belajar berupa tes membaca pemahaman. Data yang diperoleh selanjutnya dianalisis secara deskriptif dan inferensial. Dari hasil penelitian diperoleh data bahwa nilai rata-rata hasil tes membaca pemahaman siswa kelas eksperimen yang diajar dengan menggunakan metode PQ4R adalah sebesar 85,00 sementara nilai rata-rata untuk kelas kontrol yang diajar dengan metode konvensional adalah 75,00. Lebih lanjut, berdasarkan hasil uji hipotesis dengan menggunakan statistik inferensial diperoleh bahwa $t_{\text {hitung }}=7,393$ dimana $t_{\text {tabel }}=1,697$ dengan taraf signifikan 0,05 . Berdasarkan data tersebut diketahui bahwa $t_{\text {hitung }}>t_{\text {tabel }}$ sehingga $H_{1}$ diterima dan $H_{o}$ ditolak. Dengan demikian dapat disimpulkan bahwa terdapat pengaruh penerapan metode pembelajaran PQ4R terhadap kemampuan membaca pemahaman siswa kelas V sekolah dasar.
\end{abstract}

Kata kunci: metode pembelajaran PQ4R; membaca pemahaman

\begin{abstract}
The purpose of this study was to determine the effect of applying the PQ4R method to students' reading comprehension abilities. This type of research used in this research is quantitative research that is true experimental by using pretest-posttest control group design. This study involved 51 fifth grade elementary school students as a research sample divided into two classes, namely the experimental class and the control class. The instrument used was a learning achievement test in the form of reading comprehension tests. The data obtained were then analyzed descriptively and inferentially. From the results of the study obtained data that the average value of the reading test reading comprehension of the experimental class students taught using the PQ4R method amounted to 85.00 while the average value for the control class taught with the conventional method was 75.00. Furthermore, based on the results of hypothesis testing using inferential statistics obtained that $\mathrm{t}_{\text {count }}=7.393$ where $\mathrm{t}_{\text {table }}=$ 1.697 with a significant level of 0.05 . Based on these data it is known that $t_{\text {count }}>t_{\text {table }}$ so that $\mathrm{H}_{1}$ is accepted and $\mathrm{H}_{\mathrm{o}}$ is rejected. Thus it can be concluded that there is an effect of the application of the PQ4R learning method to the reading ability of students
\end{abstract}


in grade $\mathrm{V}$ in elementary school.

Keywords: PQ4R learning method, reading comprehension

\section{PENDAHULUAN}

Bahasa mempunyai peran yang sangat penting dalam kegiatan pembelajaran karena bahasa akan membantu siswa untuk menemukan serta menggunakan keterampilan yang ada pada dirinya dalam mengungkapkan gagasan, pikiran dan perasaan. Bahasa adalah salah satu hal yang paling penting dalam kehidupan manusia. Bahasa berperan sebagai penghubung antar manusia, sehingga mereka bisa saling berkomunikasi dan bahasa yang digunakan adalah Bahasa Indonesia. Selain itu, bahasa Indonesia dapat digunakan sebagai sarana untuk memperoleh pengetahuan dan keterampilan. Akan tetapi, untuk dapat menguasai keterampilan berbahasa dibutuhkan proses latihan yang cukup intensif (Nurhaedah, Muslimin \& Kamal, 2019).

Keterampilan berbahasa mencakup empat aspek yaitu keterampilan menyimak, keterampilan berbicara, keterampilan membaca dan keterampilan menulis (Slamet, 2008). Adanya pandangan yang mengatakan bahwa: (1) orang yang rajin membaca dianggap sebagai orang kutu buku, (2) sikap yang menganggap bahwa banyak membaca tidak ada bedanya dengan sedikit membaca, tidak ada pengaruhnya dalam berbagai kegiatan hidup dan (3) budaya santai, orang dapat sukses dengan menghalalkan segala cara tanpa mau bersusah payah membaca dalam artian memperoleh pengetahuan. Hal tersebut menunjukkan bahwa membaca pemahaman dan budaya akan membaca masih rendah, terbukti dengan banyaknya anggapan yang menyudutkan kegiatan membaca. Inilah yang dapat mematahkan semangat belajar kedepan dan secara tidak langsung telah berakar dalam diri dan pikiran.

Upaya yang dapat dilakukan untuk mengembangkan membaca pemahaman diantaranya melalui pendidikan dasar. Dalam hal ini Sekolah Dasar (SD) sebagai penggegas pertama pendidikan dasar yang harus mampu membekali lulusannya dengan sikap membudayakan membaca sehingga memiliki keinginan dan kemampuan membaca yang baik sebagai bekal awal menuju jenjang yang lebih tinggi dan yang menjadi tanggung jawab utama disini adalah guru SD. Selain itu, perpustakaan dapat dijadikan sebagai wahana atau media dan sarana untuk menunjang kegiatan proses belajar mengajar (PBM) di tingkat sekolah dalam hal membaca. Olehnya itu, perpustakaan juga berperan sebagai sumber belajar yang efektif serta memiliki manfaat yang cukup besar bagi setiap siswa untuk melatihkan kemampuan membaca (Riska, 2019).

Berdasarkan observasi yang dilakukan di SD Inpres Tetebatu Kabupaten Gowa bulan Juli 2019 lalu, nilai KBM untuk pelajaran bahasa Indonesia kelas $\mathrm{V}$ yaitu 75 . Hal ini menunjukkan bahwa hasil belajar dalam pembelajaran membaca siswa masih rendah dan kurang terarah dari guru sehingga berdampak pada membaca pemahaman siswa. Terlihat dalam proses pembelajaran, ketika siswa ditugaskan untuk membaca teks bacaan dan menceritakannya kembali, hanya ada beberapa siswa yang fokus dalam kegiatan membaca, sedangkan yang lain membaca, namun sambil bercerita dengan temannya, dan siswa mengulang-ulangi kegiatan membaca sehingga menyita waktu lama. Terbukti pada saat siswa diminta menceritakan kembali isi bacaan, mereka kesulitan dan kurang memahami isi bacaan.

Selain dari itu, dilihat dari aspek guru yang kurang maksimal dalam melaksanakan dan mengarahkan pembelajaran membaca di kelas. Guru hanya meminta siswa membaca tes bacaan dan menceritakannya kembali tanpa adanya arahan cara membaca yang baik dan efektif seperti penggunaan strategi dan metode yang tepat dalam membaca. Oleh karena itu dibutuhkan kreativitas guru dalam mengelola pembelajaran dengan menerapkan model pembelajaran yang efektif untuk mengajarkan suatu konsep yang memungkinkan dapat menarik minat siswa ketika menyampaikan materi ajar kepada siswa (Syamsuddin, Jannah \& Kristiawati, 2019).

Berkaitan dengan kondisi sebelumnya, diperlukan upaya-upaya untuk meningkatkan motivasi siswa dalam membaca pemahaman. Hal ini menggambarkan suatu upaya untuk meningkatkan kemampuan siswa dalam mempelajari atau menguasai suatu konten yang diajarkan melalui penerapan metode atau media pembelajaran yang efektif, menarik, dan menyenangkan bagi siswa (Syamsuddin \& Lukman, 2019).

Pembelajaran dikatakan menyenangkan apabila selama proses pembelajaran terdapat 
suasana yang rileks, bebas dari tekanan, aman, menarik, bangkitnya minat belajar, adanya keterlibatan penuh, perhatian siswa tercurah, lingkungan belajar yang menarik, bersemangat, serta disertai konsentrasi yang tinggi (Rosmalah, Hasdiana \& Satriani, 2019).

Dalam hal ini peneliti menerapkan metode pembelajaran PQ4R untuk mengantarkan siswa menguasai materi tentang membaca pemahaman. Menurut Abidin (2012) metode yang dapat digunakan oleh guru pada saat pembelajaran membaca pemahaman adalah metode Preview, Question, Read, Reflect, Recite and Review (PQ4R). Menurut Yuriardi (2013) metode PQ4R adalah suatu metode membaca yang digunakan untuk membantu siswa berpikir kritis dengan memanfaatkan daya ingat siswa sehingga dapat membantu siswa memahami suatu bacaan.

Menurut Altabany (2014) metode PQ4R merupakan salah satu bagian strategi elaborasi. Strategi ini digunakan untuk membantu siswa mengingat apa yang mereka baca, dan dapat membantu proses belajar mengajar dikelas yang dilaksanakan dengan kegiatan membaca buku. Pratiwi dalam Trianto (2007) mengungkapkan metode PQ4R merupakan salah satu bagian dari strategi elaborasi.

Strategi ini digunakan untuk membantu siswa mengingat apa yang mereka baca dan dapat membantu proses pembelajaran di kelas yang dilaksanakan dengan kegiatan membaca buku. Kegiatan membaca buku bertujuan untuk mempelajari sampai tuntas bab demi bab suatu buku pelajaran. Oleh karena itu keterampilan pokok pertama yang harus dikembangkan dan dikuasai oleh siswa adalah membaca buku pelajaran dan bacaan tambahan lainnya (Riska, 2019).

Menurut Abidin (2012) tahapan metode PQ4R dilaksanakan dalam enam tahap yaitu: "(1) membaca sekilas (preview), (2) membuat pertanyaan (question), (3) membaca dalam hati (read), (4) merefleksi (reflect), (5) menceritakan kembali (recite) dan (6) meninjau kembali (review)". Metode PQ4R memiliki beberapa keunggulan (Riadi, 2013) yang dijabarkan sebagai berikut.

1) Sangat tepat digunakan untuk pengajaran pengetahuan yang bersifat deklaratif berupa konsep-konsep, definisi, kaidah-kaidah, dan pengetahuan penerapan dalam kehidupan sehari-hari.
2) Dapat membantu siswa yang daya ingatannya lemah untuk menghafal konsep-konsep pelajaran.

3) Mudah diterapkan pada semua jenjang pendidikan.

4) Mampu membantu siswa dalam meningkatkan keterampilan proses bertanya dan mengomunikasikan pengetahuannya.

5) Dapat menjangkau materi pelajaran dalam cakupan yang luas.

Sementara kelemahan dari metode PQ4R adalah sebagai berikut.

1) Tidak tepat diterapkan pada pengajaran pengetahuan yang bersifat prosedural seperti pengetahuan keterampilan.

2) Sangat sulit dilaksanakan jika sarana seperti buku siswa (buku paket) tidak tersedia di sekolah.

Penerapan metode PQ4R untuk meningkatkan kemampuan membaca pemahaman siswa menjadi tujuan dari penelitian ini. Dimana Dalman (2017) menyatakan bahwa membaca pemahaman merupakan keterampilan membaca yang berada pada urutan yang lebih tinggi. Membaca pemahaman adalah membaca secara kognitif (membaca untuk memahami). Membaca pemahaman merupakan kegiatan membaca yang dilakukan secara intensif agar pembaca mendapatkan pemahaman yang menyeluruh dan mendalam terhadap isi bacaan.

Dalam membaca pemahaman pembaca dituntut untuk memahami isi bacaan. Pembaca harus mampu menguasai dan memahami bacaan yang dibacanya. Dalam hal ini, unsur yang harus ada dalam setiap kegiatan membaca adalah pemahaman. Pada dasarnya membaca pemahaman merupakan kelanjutan dari membaca permulaan. Apabila seorang pembaca telah melalui tahap membaca pemahaman atau membaca lanjut. Disini seseorang pembaca tidak lagi dituntut bagaimana ia melafalkan huruf dengan benar dan merangkaikan setiap bunyi bahasa menjadi bentuk kata,frasa dan kalimat. Tetapi disini ia dituntut untuk memahami isi bacaan yang dibacanya.

Pembelajaran membaca pemahaman menggunakan teknik skema merupakan salah satu upaya tepat karena dengan teknik skema, siswa harus menghubungkan pengalamannya dengan pengalaman yang ada dalam buku teks (Saiful, 2018). Lebih lanjut, Saiful (2018) menyatakan bahwa melalui aktivitas membaca yang baik dan benar yaitu anak mampu mengambil intisari bacaan yang dibacanya, anak bisa mendapatkan sesuatu dari aktivitas 
membaca yang ia lakukan. Semakin banyak intisari yang bisa dipahami dari bahan bacaannya maka semakin banyak pula pengetahuan yang anak peroleh.

Dengan demikian dapat dikemukakan bahwa salah satu tujuan membaca pemahaman adalah untuk memahami suatu bacaan secara menyeluruh yang meliputi kemampuan untuk meneukan ide pokok, mampu menangkap makna tersirat maupun tersurat, memperoleh fakta dari suatu bacaan, menentukan topik maupun judul serta dapat membuat simpulan dari isi bacaan.

\section{METODE PENELITIAN}

Penelitian yang digunakan adalah penelitian kuantitatif yang sifatnya true experimental design dengan pretest-posttest control group design. Penelitian ini disebut true experimental design karena kelompok eksperimen dan kelompok kontrol pengambilannya dilakukan secara random. Ciri utama dari true experimental design adalah sampel yang digunakan untuk kelompok eksperimen maupun sebagai kelompok kontrol diambil secara random dari populasi tertentu.

Penentuan kelompok eksperimen dan kelompok kontrol dilakukan dengan secara acak (random), kemudian diberi pretest untuk mengetahui kemampuan awal siswa dan diberi posttest untuk mengetahui kemampuan ahkir siswa. Terdapat 51 siswa kelas V Sekolah Dasar Inpres Tetebatu dimana 30 siswa yang bertindak sebagai kelas eksperimen dan 21 siswa sebagai kelas kontrol.

Instrumen yang digunakan dalam penelitian ini adalah tes membaca pemahaman untuk siswa kelas V sekolah dasar. Data yang diperoleh dari instrumen tersebut dianalisis dengan menggunakan analisis statistik deskriptif dan statistik inferensial untuk menguji hipotesis yang diajukan dalam penelitian ini.

\section{HASIL DAN PEMBAHASAN}

Hasil penelitian yang telah dilakukan oleh peneliti dideskripsikan secara rinci untuk masing-masing variabel. Pembahasan variabel dilakukan dengan menggunakan data kuantitatif yaitu data yang diolah berbentuk angka atau skor kemudian ditafsirkan secara deskriptif.

Data variabel yang dideskripsikan dalam penelitian ini, yaitu (1) data variabel bebas (variabel X) yaitu penggunaan penerapan metode Preview, Question, Read, Reflect, Recite and Review (PQ4R) (2) data variabel terikat (variabel Y) yaitu nilai hasil belajar mata pelajaran Bahasa Indonesia berupa tes membaca pemahaman.

1. Hasil Observasi Aktivitas Belajar SD Inpres Tetebatu

Berdasarkan hasil observasi yang dilakukan diperoleh data bahwa aktifitas siswa SD Inpres Tetebatu mengalami peningkatan dari $66 \%$ menjadi $74,1 \%$. Hal ini terjadi karena dipengaruhi oleh penggunaan atau penerapaan metode pembelajaran Preview, Question, Read, Reflect, Recite and Review (PQ4R).

2. Hasil belajar SD Inpres Tetebatu

Berikut disajikan gambaran ketuntasan belajar terkait kemampuan membaca pemahaman siswa di SD Inpres Tetebatu yang dijabarkan pada tabel di bawah ini.

Tabel 1: Perbandingan ketuntasan belajar membaca pemahaman siswa kelas $\mathrm{V}$ SD Inpres Tetebatu

\begin{tabular}{cccccc}
\hline \multirow{2}{*}{ No } & \multirow{2}{*}{$\begin{array}{c}\text { Kategori } \\
\text { Ketuntasan }\end{array}$} & \multicolumn{2}{c}{ Tuntas } & \multicolumn{2}{c}{ Tidak } \\
\cline { 3 - 6 } & Tuntas \\
\hline 1 & Kelas kontrol & 21 & 68 & F & \% \\
\hline 2 & $\begin{array}{l}\text { Kelas } \\
\text { eksperimen }\end{array}$ & 30 & 100 & 0 & 0 \\
\hline
\end{tabular}
ketuntasan belajar Bahasa Indonesia terutama pada materi membaca pemahaman pada kelas eksperimen mencapai $100 \%$ sehingga semua siswa yang mengikuti pembelajaran dengan metode PQ4R memenuhi standar KKM yang ditentukan. Sementara untuk kelas kontrol masih terdapat 10 siswa atau sekitar $32 \%$ yang nilai tes hasil belajarnya belum memenuhi nilai KKM yang ditentukan oleh sekolah. Ketuntasan hasil belajar juga dapat dijabarkan melalui grafik seperti gambar di bawah ini.

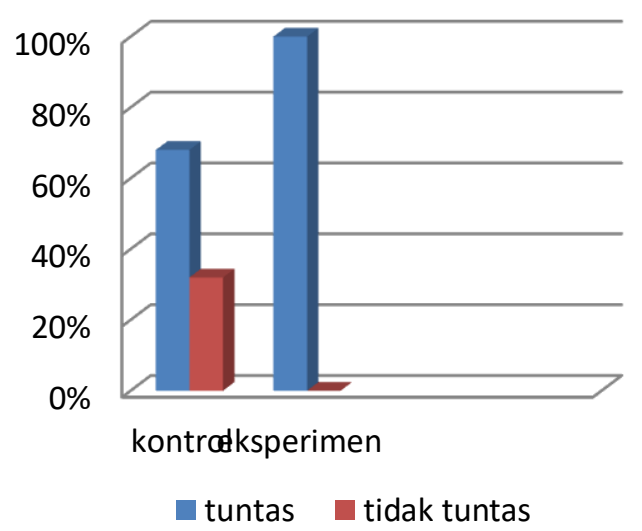

Gambar 1. Perbandingan hasil ketuntasan belajar Bahasa Indonesia 
Dari gambar di atas, jelas terlihat bahwa ketuntasan belajar persentasinya lebih banyak pada kelas eksprimen dengan menggunakan metode PQ4R sementara kelas kontrol lebih banyak tidak tuntas dengan menggunakan metode konvensional Berdasarkan data observasi aktivitas siswa di SD Inpres Tetebatu pada penejelasan sebelumnya diperoleh gambaran bahwa terjadi peningkatan aktivitas siswa dari $66 \%$ menjadi $74,1 \%$. Hal ini dipengaruhi oleh penggunaan metode pembelajaran dimana kelas kontrol menggunakan metode konvensional sedangkan kelas eksperimen menggunakan Penerapan metode Preview, Question, Read, Reflect, Recite and Review (PQ4R).

Hal ini diperkuat oleh seorang ahli yang bernama Yulianti (2013) metode PQ4R adalah suatu metode membaca yang digunakan untuk membantu siswa berfikir kritis dengan memanfaatkan daya ingat siswa sehingga dapat membantu siswa memahami suatu bacaan PQ4R dilahirkan atas pendapat bahwa pembaca dapat mengembangkan keterampilan membacanya karena PQ4R merupakan metode yang efektif untuk membantu pembaca berpikir kritis dalam memahami suatu bacaan dan mengingatnya dalam waktu panjang sehingga pembaca memiliki cadangan pengetahuan.

Hal senada yang dikemukakan oleh Trianto (2007) bahwa metode PQ4R dapat mengaktifkan pengetahuan awal siswa dan mengawali proses pembuatan hubungan antara informasi baru dengan apa yang telah diketahui sebelumnya. Selain itu, metode PQ4R membantu siswa mengingat apa yang telah dibaca/efektif membantu siswa menghafal informasi dari bacaan. Metode PQ4R membantu siswa memahami suatu bacaan. Metode PQ4R memotivasi siswa untuk belajar sendiri. Metode PQ4R membantu siswa berpikir kritis serta metode PQ4R meningkatkan konsentrasi siswa terhadap isi bacaan.

Selanjutnya, dilakukan uji hipotesis dengan menggunakan analisis statistik inferensial dimana Jika $t_{\text {hitung }}>t_{\text {tabel }}$, maka $H_{1}$ diterima dan $\mathrm{H}_{0}$ ditolak. Dari perhitungan statistik diperoleh gambaran data dengan menggunakan taraf signifikan 0,05 dimana $t_{\text {hitung }}$ $=7,393$ dan $t_{\text {tabel }}=1,697$ sehingga dapat dinyatakan bahwa $t_{\text {hitung }}>t_{\text {tabel }}$. Oleh karena itu dapat disimpulkan $\mathrm{H}_{1}$ diterima dan Ho ditolak. Hasil ini juga ditunjukkan oleh nilai signifikan uji statistik yaitu 0,000 . Sehingga dapat dikemukakan bahwa terdapat pengaruh penerapan PQ4R terhadap hasil belajar bahasa Indonesia siswa pada materi membaca pemahaman

\section{SIMPULAN DAN SARAN}

Berdasarkan hasil penelitian yang dilakukan, diperoleh gambaran data tentang kemampuan membaca siswa kelas V SD Inpres Tetebatu. Untuk kelas kontrol dengan mengguanakan metode konvensonal diperoleh nilai rata-rata 75 sementara untuk kelas eksperimen yang menggunakan metode PQ4R diperoleh nilai rata-rata 85 .

Berdasarkan hasil analisis data, diketahui $t_{\text {tabel }}=1,697$ dan $t_{\text {hitung }}=7,393$. Dengan demikian $t_{\text {hitung }}>t_{\text {tabel }}$ sehingga $H_{o}$ ditolak dan dapat disimpulkan bahwa terdapat perbedaan yang signifikan antara hasil belajar kelas konvensional dan kelas eksperimen dengan menggunakan metode PQ4R. Dimana dengan menerapkan metode PQ4R dapat mempengaruhi hasil belajar siswa pada materi membaca pemahaman kelas $\mathrm{V}$ Sekolah Dasar di Kecamatan Pallangga Kabupaten Gowa.

Oleh karena itu, metode Preview, Question, Read, Reflect, Recite and Review (PQ4R) dapat dijadikan sebagai salah satu alternatif motode yang dapat diterapkan dalam rangka meningkatkan kemampuan membaca pemahaman siswa.

\section{DAFTAR RUJUKAN}

Abidin, Y. 2012. Pembelajaran bahasa berbasis pendidikan karakter. Refika Aditama.

Dalman. 2015. Menulis karya ilmiah. Depok: Rajagrafindo Persada.

Nurhaedah, Muslimin \& Kamal. 2019. Pengaruh Model Pembelajaran Paired story telling Terhadap Keterampilan Menulis Karangan Narasi Pada Muatan Bahasa Indonesia Siswa Kelas V SD Negeri Kompleks IKIP I Kota Makassar. JIKAP PGSD: Jurnal Ilmiah Ilmu Kependidikan, 3 (3): 196-203.

Riska, A. 2019. Pemanfaatan Perpustakaan Sekolah Sebagai Sumber Belajar Siswa SD Inpres 12/79 Biru II Kecamatan Tanete Riattang Kabupaten Bone. JIKAP PGSD: Jurnal Ilmiah Ilmu Kependidikan, 3 (2): 82-92.

Rohimat, A. 2013. Penerapan Teknik Copy The Master Dalam Pembelajaran Menulis Karangan Persuasi Pada Siswa Kelas $X-2$ Sma Pasundan 7 Bandung Tahun Ajaran 2012/2013 (Doctoral dissertation, 
JIKAP PGSD: Jurnal Ilmiah Ilmu Kependidikan

Universitas Pendidikan Indonesia).

Rosmalah, Hasdiana \& Satriani. 2019. Pengaruh Ice breaking terhadap Minat Belajar Siswa Kelas V SD Negeri 10 Manurunge Kecamatan Tanete Riattang Kabupaten Bone. Jurnal. JIKAP PGSD: Jurnal Ilmiah Ilmu Kependidikan, 3 (3): 204-210.

Saiful, M. 2018. Peningkatan Kemampuan Membaca Pemahaman Dengan Teknik Skema Pada Siswa Kelas XI IPA-2 SMA Negeri 2 Watampone Kabupaten Bone. JIKAP PGSD: Jurnal Ilmiah Ilmu Kependidikan, 2 (1): 31-41.

Sardiman, A. M. 2004. Interaksi dan motivasi belajar-mengajar. Jakarta: Rajawal

Slamet.. 2008. Dasar-Dasar Keterampilan Berbahasa Indonesia. Surakarta: UNS Press

Syamsuddin, A., Jannah, M., \& Kristiawati, K. 2019. Penerapan Model Explicit Instruction dalam Pembelajaran Matematika Materi Bilangan Romawi Pada Siswa Kelas IV SD Inpres Kapasa Makassar. MaPan: Jurnal Matematika dan Pembelajaran, 7 (1): 136-154.

Syamsuddin, A., \& Lukman, A. 2019. Penggunaan Media Edukasi Hitung Kompak dan Dampaknya Terhadap Kemampuan Berhitung Siswa Sekolah Dasar. JRPD (Jurnal Riset Pendidikan Dasar), 2 (1): 1-8.

Trianto, S. P., \& Pd, M. 2007. Model-model pembelajaran inovatif berorientasi Konstruktivistik. Jakarta: Prestasi Pustaka.

Yulianti, L. Eva, Wirya,, Nyoman, dan Arini, Ni Wayan. 2013. Penerapan Metode PQ4R (Preview, Question, Read, Reflect, Recite, Review) Untuk Meningkatkan Keterampilan Membaca Pada Mata Pelajaran Bahasa Indonesia Di SD. Jurnal Mimbar PGSD Undiksha, 1 (1). 